\title{
Climatic significance of tree-ring width and intra-annual density fluctuations in Pinus pinea from a dry Mediterranean area in Portugal
}

\author{
Filipe CAMPELO $^{\mathrm{a} *}$, Cristina NABAIS ${ }^{\mathrm{a}}$, Helena FreITAS $^{\mathrm{a}}$, Emilia GuTIÉRREZ $^{\mathrm{b}}$ \\ a Departamento de Botânica, Universidade de Coimbra, Calçada Martim de Freitas, 3001-455 Coimbra, Portugal \\ ${ }^{\mathrm{b}}$ Departament d'Ecologia, Facultat de Biologia, Universitat de Barcelona, Av. Diagonal, 645, 08028 Barcelona, Spain
}

(Received 10 April 2006; accepted 19 June 2006)

\begin{abstract}
In Mediterranean climates trees may go through two periods of dormancy, resulting in special anatomical features such as false rings and other intra-annual density fluctuations (IADFs). In this paper, ring growth and the presence of IADFs were studied in Pinus pinea L. growing in the coastal and inland regions of Alentejo (southern Portugal). In order to identify the triggering factors associated with the IADFs, a new classification was proposed for the IADFs in P. pinea: Type $E$ (latewoodlike cells within earlywood); Type $E+$ (transition cells between earlywood and latewood); Type $L$ (earlywoodlike cells within latewood) and Type $L+$ (earlywoodlike cells between latewood and earlywood of the next tree ring). Response function analyses showed that radial growth of $P$. pinea was strongly correlated with precipitation in southern Portugal. The climatic response of $P$. pinea was higher in the inland area where the summer drought is more severe, the winter temperatures are lower and the soils have low water-holding capacity, in comparison with the coastal area. IADFs were frequent in $P$. pinea and most of the IADFs were observed in latewood. The presence of IADFs was correlated with fluctuations in climate parameters during the growing season. The IADF type $E+$ was linked to precipitation events early in summer. The IADF type $L$ and $L+$ were associated with above-average precipitation in early autumn.
\end{abstract}

false tree-ring / Mediterranean climate / Pinus pinea / radial growth / wood anatomy

Résumé - Signification climatique de la largeur des cernes et des fluctuations intra annuelles de la densité chez Pinus pinea dans une région méditerranéenne sèche du Portugal. Dans les climats méditerranéens, les arbres peuvent traverser deux périodes de dormance, ce qui a pour conséquence des caractéristiques anatomiques particulières telles que des faux cernes et des fluctuations intra annuelles de densité (IADFs). Dans cet article, la croissance des cernes et la présence de IADFs ont été étudiées chez Pinus pinea L. poussant dans les régions côtières et intérieures de l'Alentejo (sud-ouest du Portugal). Dans le but d'identifier les facteurs déclenchants associés à l'IADFs, une nouvelle classification a été proposée pour l'IADFs chez Pinus pinea : Type $E$ (cellules ressemblant à du bois final dans le bois initial); Type $E+$ (cellules de transition entre bois initial et bois final); Type $L$ (cellules ressemblant à du bois initial dans du bois final) et Type $L+$ (cellules ressemblant à du bois initial entre bois final et bois initial du prochain cerne). Les analyses des fonctions de réponse ont montré que la croissance radiale de Pinus pinea était fortement corrélée avec les précipitations dans le sud-ouest du Portugal. La réponse climatique de Pinus pinea a été plus forte dans la zone intérieure où la sécheresse d'été est plus sévère, les températures hivernales plus basses et où les sols ont une plus faible capacité de rétention de l'eau, comparativement aux zones côtières. IADFs a été fréquent chez Pinus pinea et la majorité d'IADFs a été observée dans le bois final. La présence d'IADFs a été corrélée avec des fluctuations des paramètres climatiques pendant la saison de croissance. L'IADFs type $E+$ était lié avec des évènements pluvieux en début d'été. L'IADFs type $L$ et l'IADFs type $L+$ étaient associés avec des précipitations supérieures à la moyenne en début d'automne.

faux cerne / climat méditerranéen / Pinus pinea / croissance radiale / anatomie du bois

\section{INTRODUCTION}

Specific intra-season climatic information is difficult to obtain from tree-ring width records [23]. As a consequence, several studies have used special features or anomalies in radial growth for ecological and climatological interpretation $[11,60,61]$. Such studies have included frost rings [9, 35], light rings $[20,36,58,64]$, and the formation of intra-annual density fluctuations (IADFs) [12, 46, 47, 62]. In the literature IADFs have also been referred to as "double rings" [22], "false rings" [51], "multiple growth layers" [26], "multiple rings" [32] or "intra-annual growth bands" [23]. An IADF occurs when unusual conditions interrupt normal radial growth, pro-

\footnotetext{
*Corresponding author: fcampelo@ci.uc.pt
}

ducing latewoodlike cells within the earlywood or earlywoodlike cells within the latewood [23].

Relationships between climate and IADF formation have been studied in various tree species. Wimmer et al. [62] demonstrated a relationship between the precipitation in May and IADF formation in earlywood for Austrian pine (Pinus nigra Art.). Rigling et al. [46], working with Scots pine (Pinus sylvestris L.) from semiarid sites in central Alps (Switzerland), found relationships between IADF formation in the latewood and cool-moist July and August. However, no relationship was found between climate and IADF production for semiarid sites in central Russia [46]. In fact, under such short growing period the monthly climatic data were not sufficiently precise to describe the controlling factors of IADFs [46]. 


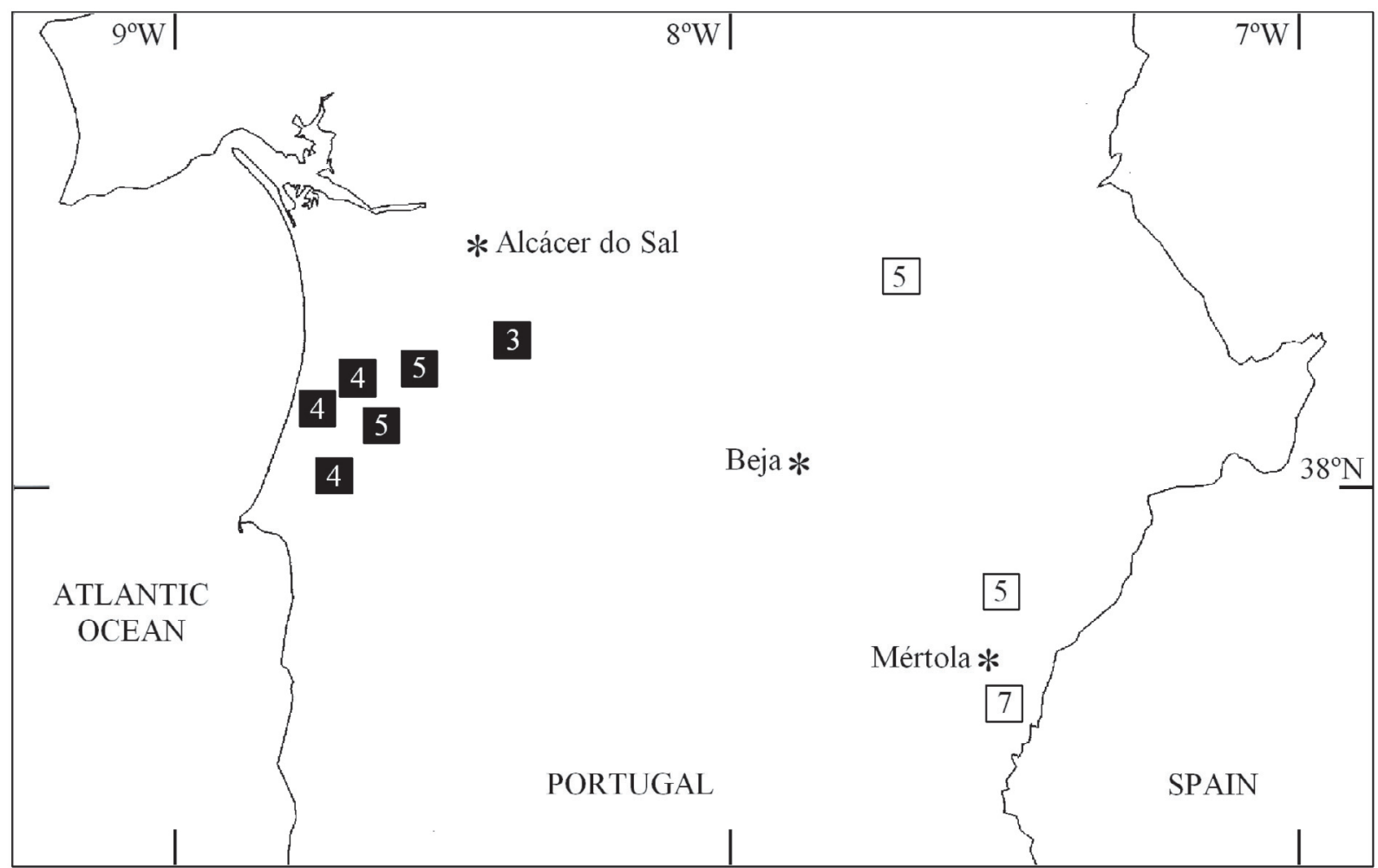

Figure 1. Location of the study areas and the meteorological stations $(*)$. The full squares and the open squares indicate the sampling sites in the coastal area and in the inland area, respectively. The digits inside the squares represent the number of trees used per site.

IADFs have also been studied in hardwoods. Priya and Bhat [45] found that dry conditions in May followed by moist summers could cause IADF formation in the earlywood of teak (Tectona grandis L.f.). They were able to establish a relationship between IADF occurrence in latewood and abundant rainfall during the late growing season. IADFs in teak have also been observed in association with insect defoliation [44]. In southern Patagonia (Argentina), Masiokas and Villalba [40] noted that anomalously dry warm springs followed by wet-warm late summers caused IADFs in Nothofagus pumilio (Poepp et Endl.) Krasser.

According to Bouriaud et al. [5], wood density of Norway spruce (Picea abies (L.) Karst.) responded strongly to drought events, and a dry period could induce IADF formation. These authors also found that wood density was influenced by climatic fluctuations only during the second half of the growing season. Camarero et al. [10] pointed out a possible delay between the triggering climatic factor and the occurrence of the IADF. Rigling et al. [46] have argued that it would be almost impossible to determine with precision when the controlling event had occurred based on the relative position of the IADF. This can hold true for trees growing under short growing seasons as in high elevations or at high latitudes. However, there is a lack of studies at low elevations and low latitudes, where the trees experience long growing seasons. Moreover, IADF studies to date have only considered the presence of the IADF over entire annual rings, or in earlywood and latewood parts of annual rings. Studies that take into account the relative po- sition of the IADF within earlywood and latewood are needed to establish a more precise temporal relation between the triggering event and IADF formation.

The aims of this work were (i) to identify relationships between radial growth in Pinus pinea and climate (ii) to quantify the presence of different types of IADFs in $P$. pinea growing in the coastal and inland regions of Alentejo (southern Portugal), and (iii) to establish the relationships between IADFs and climate.

\section{MATERIAL AND METHODS}

\subsection{Study areas}

The study areas were located in southwestern and southeastern Portugal, hereafter coastal area and inland area, respectively (Fig. 1). The sites were located at low altitude, varying from 30 to $270 \mathrm{~m}$ above sea level in the coastal area and from 140 to $230 \mathrm{~m}$ in the inland area. The climate of both areas is typically Mediterranean, with a marked summer drought and limited precipitation occurring mainly from late autumn to early spring (Fig. 2). In the coastal area, the nearest meteorological station is Alcácer do Sal, whereas for the inland area the closest stations are Beja and Mértola (Fig. 1). In the inland area, the soils are mainly lithosols, shallow and poorly developed with low nutrients and low water-holding capacity. The major soil types in the coastal area are cambisols, with higher water-holding capacity. 

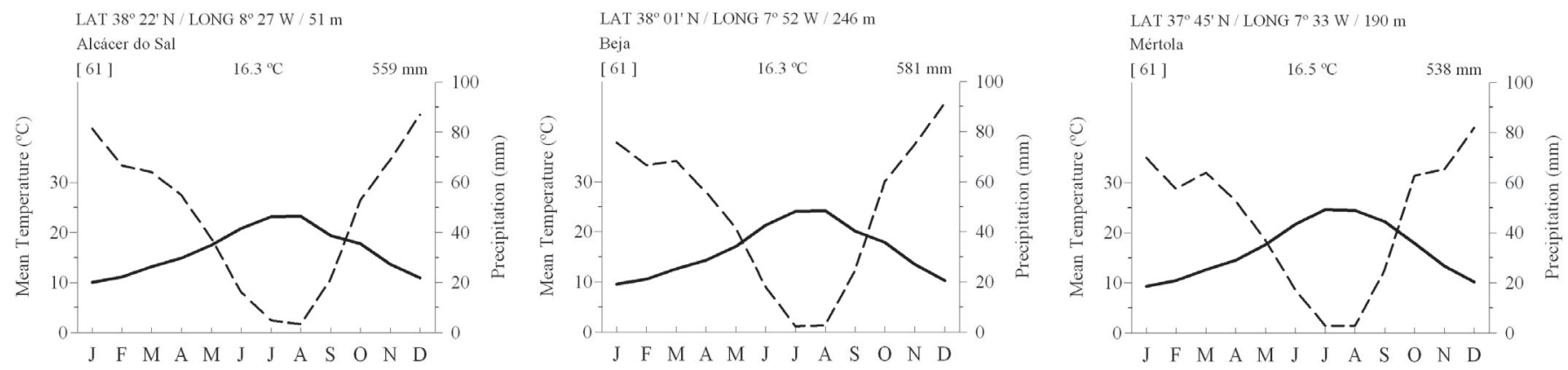

Figure 2. Ombrothermic diagrams of meteorological stations close to the study areas, for the period 1941-2002. Data from Instituto Nacional de Meteorologia, Portugal. Precipitation is represented by the dash line and temperature by the solid line.

\subsection{Tree-ring data}

Thirty trees were sampled in the coastal area and twenty in the inland area taking two increment cores per tree at breast height $(1.3 \mathrm{~m})$, between 2003 and 2004. In each site at least 5 dominant, old and large stem trees $P$. pinea were sampled. The increment cores were air dried, mounted on wooden supports and sanded with progressively finer grades of sandpaper to produce a flat, polished surface on which tree-ring boundaries and individual tracheids were clearly visible under magnification. Trees having less than 40 rings were rejected. Trees with at least one core showing wounds and/or missing rings caused by resin extraction or fire were also excluded. The remaining cores were used to establish the master chronologies and the IADFs frequency. In total, 25 trees were selected for the coastal area and 17 trees for the inland area.

The tree rings on all cores were cross-dated by using both the list method [63] and the skeleton plots [54] to ensure that each ring was dated to the correct calendar year of formation. Tree-ring width, earlywood and latewood widths were measured with an accuracy of $0.01 \mathrm{~mm}$, using the linear table Lintab (Frank Rinn S.A., Heidelberg, Germany) and the program TSAP-Win [48]. Cross-dating quality and measurements errors were evaluated using COFECHA [29].

Earlywood, latewood and tree-ring width chronologies were established for each area using the program ARSTAN [13]. Lowfrequency growth trends were removed by fitting a cubic spline curve with a $50 \%$ frequency cutoff of 40 years to each ring width time series [15]. Autoregressive modelling was performed on each standardized series to remove temporal autocorrelation [6] in order to maximize the climatic signal $[14,17]$. Chronologies were obtained by averaging the index series (cores were maintained as distinct records) using a biweight robust mean to reduce the influence of outliers [16].

Chronology quality was assessed using standard deviation (SD), mean sensitivity (MS) and expressed population signal (EPS). The EPS determines how well a chronology established on a finite number of trees approximates the theoretical population chronology [8, 59]. Because the sample depth declines in the early portions of these chronologies, the subsample signal strength (SSS) statistic was used to determine the minimum number of trees that should be used to give a reliable estimate of the mean chronology [59].

\subsection{Response function analysis}

The climatic response of $P$. pinea earlywood, latewood and treering widths, for the period 1941-2002, was investigated using the bootstrapped response function analysis by the program PRECON $[7,24,53]$. This procedure is a particular multiple regression model where the independent variables are properly transformed in principal components. The use of bootstrap methods in this process $[27,28]$ allows us to calculate the mean correlation between the actual and predicted ring indices for the dependent data sets for which the model was developed (calibration), as well as the mean correlation between the actual and predicted ring indices for the independent data sets (verification), based on 999 random replications. The mean value of the verification correlation coefficient gives a measure of how strong the climate-growth relationship is [23]. The mean partial regression coefficients are considered significant at the 95\% level if they are twice, in absolute value, their standard deviation [28]. Response functions were calculated using the master chronology of residuals for each area and the mean monthly temperature and precipitation sum from October of the previous year $(t-1)$ to November of the current year $(t)$. Because autocorrelation was effectively reduced by the detrending and autoregressive modelling, the response functions were calculated without prior growth. For the coastal area, data from a single meteorological station (Alcácer do Sal) were used. Meteorological data from two stations (Beja and Mértola) were used to compute mean climatic data for the inland area. Program MET from the PROGLIB library was used to investigate the homogeneity of climatic data [30].

\subsection{Intra-annual density fluctuations}

Correctly dated cores were examined for IADFs with a stereomicroscope magnifying up to 25 -fold. IADFs were detected by their gradual transition in cell size and wall thickness at outer borders [57, 62]. The IADFs in $P$. pinea were classified according to their positions within the tree ring: Type $E$ characterized by latewoodlike cells within earlywood; Type $E+$ with transition cells between earlywood and latewood; Type $L$ formed by earlywoodlike cells within latewood and Type $L+$ showing earlywoodlike cells between latewood and earlywood of the next tree ring (Fig. 3).

Because of the variability of IADFs tangentially and vertically within tree rings along the stem [34], an IADF was identified only when both cores from a tree showed the same IADF in an annual growth ring.

The frequency of IADFs per year, $F$, was calculated as the ratio:

$$
F=N / n
$$

where $N$ is the number of trees that formed the same type of IADF in a given year (as evidenced on both increment cores) and $n$ the 


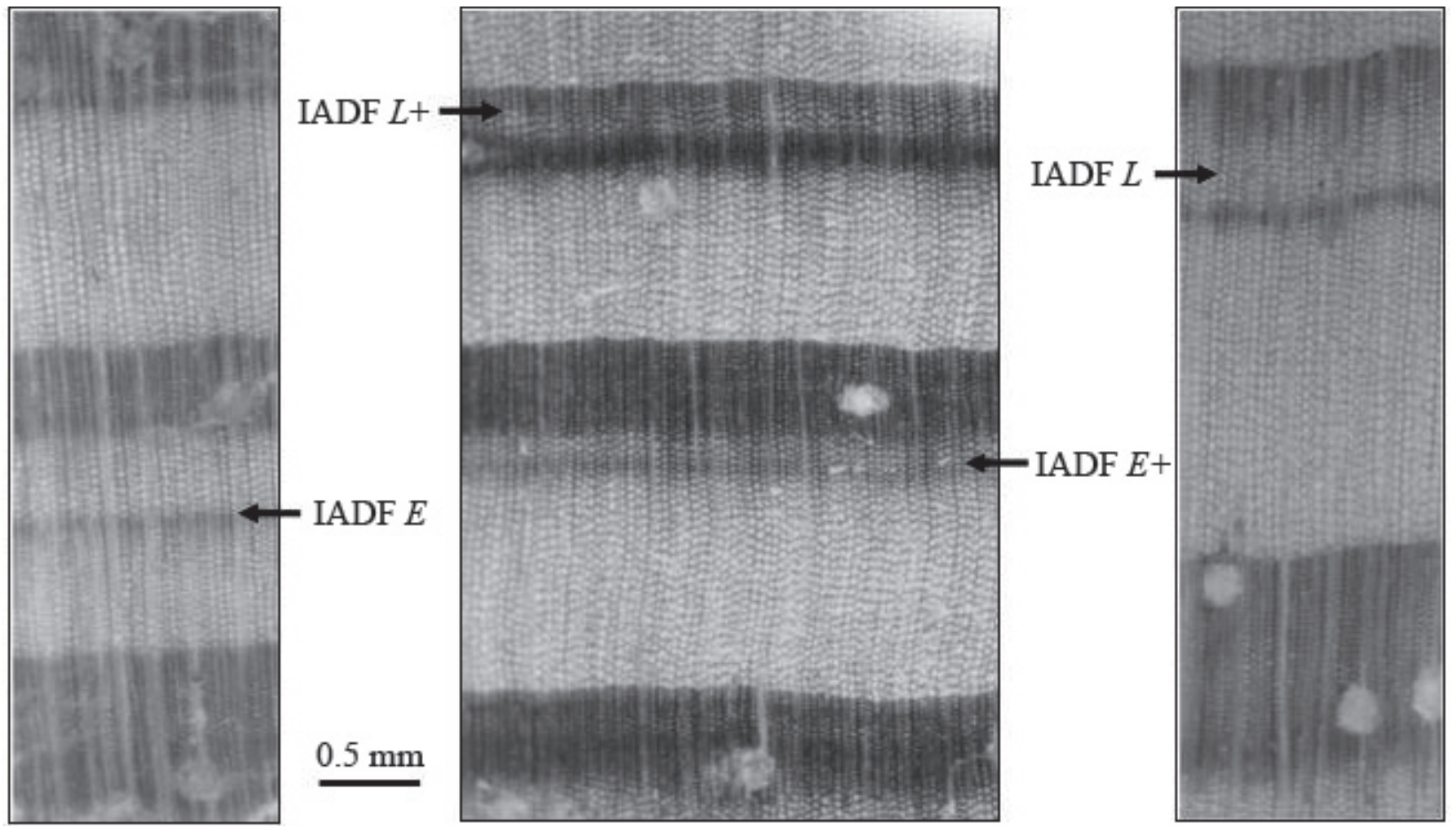

Figure 3. Anatomical structure and relative position within a tree-ring of different types of intra-annual density fluctuations (IADFs) in Pinus pinea (magnification $25 \times$ ).

number of observed trees. The changing sample depth (n) over time generates a bias for the frequency variance. To address this problem the adjustment proposed by Osborn et al. [43] was applied to improve the stability of variance:

$$
f=F n^{0.5}
$$

where $f$ is the stabilized IADF frequency.

\section{RESULTS}

\subsection{Tree-ring chronologies}

The length of the master chronologies was 108 years for the coastal area and 86 years for the inland area (Fig. 4). The expressed population signal (EPS) for all residual chronologies was higher than the critical value of 0.85 proposed by Wigley et al. [59], suggesting a strong climate signal in chronologies. $T$-tests were performed to compare the chronologies. From 1940 to 2002, the mean tree-ring width of $P$. pinea was significantly higher in the coastal area than in the inland area $(p<0.01)$. Although there were no differences for latewood width between the coastal and the inland area $(p=0.128)$, the latewood/earlywood ratio was significantly higher in the inland area $(p<0.05)$. The mean sensitivity and standard deviation for earlywood, latewood and tree-ring widths were higher in the inland area than in the coastal area (Tab. I). Values of mean sensitivity and standard deviation were higher for latewood than for earlywood and tree-ring width at each area.
In both areas, a high first-order autocorrelation was found for earlywood and tree-ring width (Tab. I).

\subsection{Climate-growth relationships}

The association between radial growth and mean monthly climate conditions were explored using response function analysis (Tab. II). The calibration correlation coefficients for earlywood, latewood and tree-ring widths were high. The latewood in the inland area showed the highest calibration and verification correlation coefficient. The percentage of variation in radial growth explained by response function models ranged from $58 \%$ to $81 \%$ (Tab. II). Climate explains $76 \%$ and $59 \%$ of the tree-ring width variance for the inland and coastal chronologies, respectively. In both areas, latewood width was more sensitive to climate variations than earlywood and treering width.

In the coastal and inland area, precipitation from November $_{(t-1)}$ to February $(t)$ had a positive effect on tree-ring and earlywood width. The same occurred when precipitation in $\mathrm{May}_{(t)}$ was higher. Higher precipitation during $\operatorname{October}_{(t)}$ led to an increase in latewood production, in both areas.

Regarding the temperature effect, tree-ring width exhibited a positive response to $\operatorname{December}_{(t-1)}$ temperature. The temperature in August had a negative effect on latewood formation, in the coastal and inland area. 


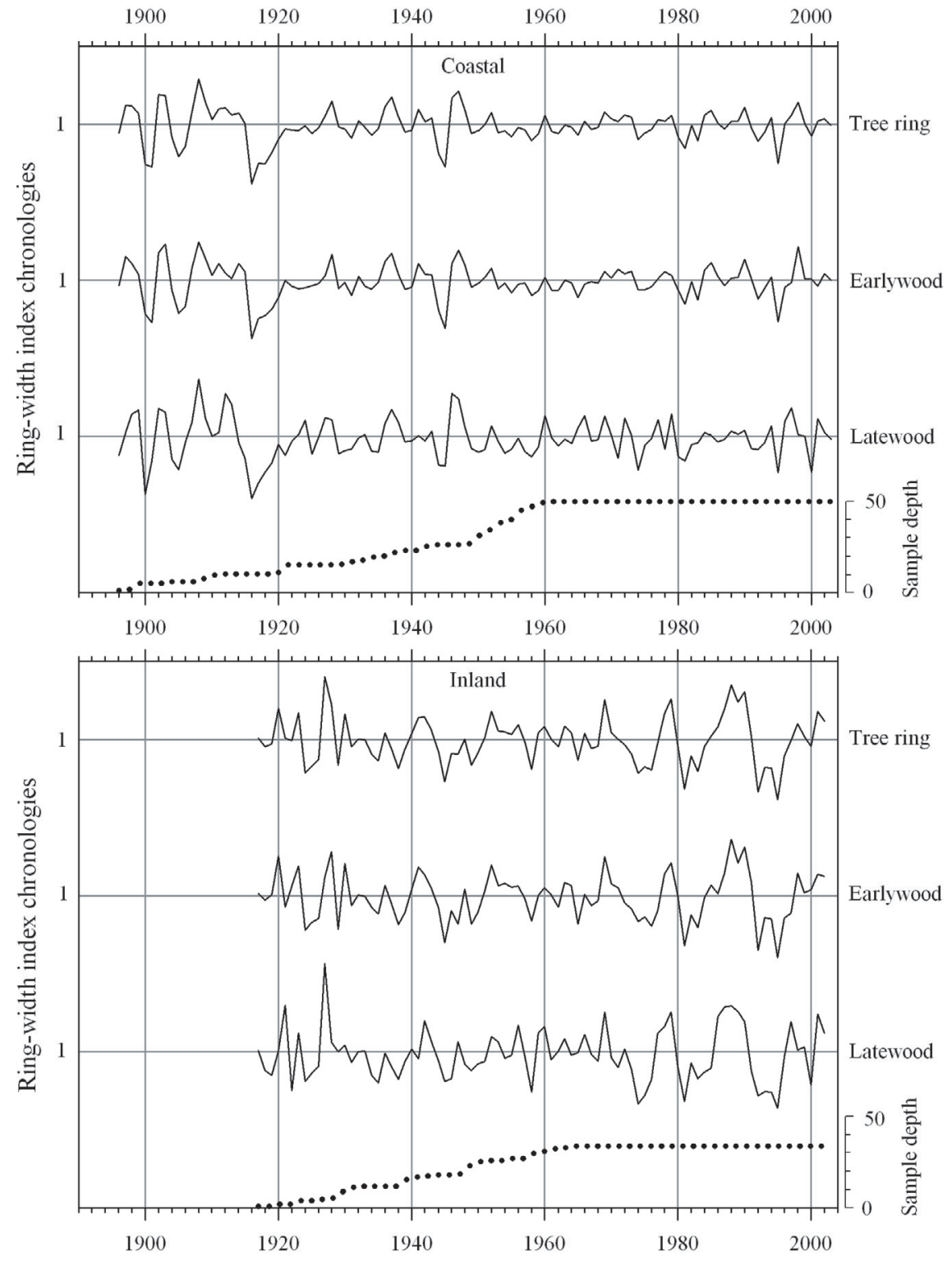

Figure 4. Ring-width indices chronologies of Pinus pinea growing in the coastal and in the inland area. The dot line represents the number of cores used.

\subsection{Intra-annual density fluctuations}

For both areas, the four types of IADFs were identified in $P$. pinea (Tab. III). Most of the detected IADFs were located in latewood (IADFs type $L$ or $L+$ ): $89.6 \%$ and $85.6 \%$ in the coastal and inland area, respectively. Occasionally, the IADFs type $E+$ and $L+$ were observed in a single tree ring. The distribution of IADFs in relation to calendar years is shown in Figure 5. The distribution of IADF type $E$ is not shown since only one tree in the inland and another in the coastal area showed this type of IADF, for the year 1952 and 1992, respectively. The trees in the coastal area had fewer years with IADFs, with stabilized frequency varying from 0 to 3.2. In the inland area the trees showed more IADFs of the different types, with stabilized frequency ranging from 0 to 2.7 (Tab. III, Fig. 5).

According to several authors $[40,46,52]$, IADFs are indicators of varying growth conditions during the growing sea- son. Therefore, the Spearman rank order correlations between the master chronologies of stabilized IADFs frequency and monthly precipitation and mean temperature were analyzed along the growing season of $P$. pinea. In both areas, higher precipitation in June $(t)$ led to a higher frequency of IADF type $E+$ (Fig. 6). In the coastal area, the frequency of IADF type $L$ was positively correlated with $\operatorname{October}_{(t)}$ precipitation, while in the inland area showed a positive correlation with precipitation in September ${ }_{(t)}$ (Fig. 6). In both areas, higher precipitation in $\operatorname{October}_{(t)}$ and November $(t)$ seemed to increase the frequency of IADF type $L+$.

\section{DISCUSSION}

Pinus pinea in the inland area showed lower mean ring widths compared to the coastal area (Tab. I). This can be attributed to the more favourable climatic conditions in the 
Table I. Descriptive statistics of the tree-ring width, earlywood and latewood width chronologies.

\begin{tabular}{|c|c|c|c|c|c|c|}
\hline & \multicolumn{3}{|c|}{ Coastal } & \multicolumn{3}{|c|}{ Inland } \\
\hline & Tree-ring & Earlywood & Latewood & Tree-ring & Earlywood & Latewood \\
\hline Start & 1896 & 1896 & 1896 & 1917 & 1917 & 1917 \\
\hline End & 2003 & 2003 & 2003 & 2002 & 2002 & 2002 \\
\hline Length (years) & 108 & 108 & 108 & 86 & 86 & 86 \\
\hline Mean (1/100 mm) & 335 & 247 & 88 & 277 & 197 & 80 \\
\hline Median (1/100 mm) & 283 & 204 & 75 & 247 & 166 & 70 \\
\hline Mean sesitivity ${ }^{\mathrm{a}}$ & 0.27 & 0.30 & 0.38 & 0.38 & 0.47 & 0.47 \\
\hline Standard deviation ${ }^{\mathrm{a}}$ & 0.336 & 0.355 & 0.411 & 0.438 & 0.468 & 0.521 \\
\hline Skewness $^{\mathrm{a}}$ & 0.496 & 0.569 & 0.848 & 0.581 & 0.75 & 1.023 \\
\hline Kurtosis $^{\mathrm{a}}$ & 1.164 & 1.278 & 1.603 & 0.996 & 1.668 & 1.942 \\
\hline First order autocorrelation ${ }^{a}$ & 0.45 & 0.42 & 0.25 & 0.49 & 0.42 & 0.35 \\
\hline First order autocorrelation ${ }^{\mathrm{b}}$ & 0.013 & 0.013 & 0.005 & 0.015 & 0.010 & 0.014 \\
\hline EPS $^{\mathrm{c}}$ Std. $^{\mathrm{a}}$ & 0.84 & 0.84 & 0.88 & 0.96 & 0.95 & 0.94 \\
\hline EPS $^{c}$ Res. $^{b}$ & 0.91 & 0.89 & 0.90 & 0.95 & 0.95 & 0.93 \\
\hline $\operatorname{SSS}^{\mathrm{d}}[\text { year }(\mathrm{n})]^{\mathrm{eb}}$ & $1921(8)$ & $1933(11)$ & $1921(9)$ & $1929(4)$ & $1930(5)$ & $1930(5)$ \\
\hline
\end{tabular}

${ }^{a}$ From standardized data series.

${ }^{\mathrm{b}}$ From residual data series.

${ }^{\mathrm{c}}$ Expressed population signal.

${ }^{\mathrm{d}}$ Subsample signal strength.

${ }^{\mathrm{e}}$ Earliest year for which SSS is $>0.85$ (number of trees needed).

Table II. Summary of the regression coefficients expressing the effects of climatic factors on chronologies of Pinus pinea. The signal of the regression coefficients are shown from $\operatorname{October}_{(t-1)}$ to November $_{(t)}$. Asterisks denote significant models at the $99.9 \%$ level.

\begin{tabular}{|c|c|c|c|c|c|c|c|c|c|c|c|c|c|c|c|c|c|c|c|c|c|c|c|c|c|c|c|c|c|c|c|c|c|}
\hline & & \multicolumn{14}{|c|}{ Temperature } & \multicolumn{14}{|c|}{ Precipitation } & \multirow[b]{2}{*}{$\mathrm{Rc}^{\mathrm{a}}$} & \multirow[b]{2}{*}{$\mathrm{Rv}^{\mathrm{b}}$} & \multirow[b]{2}{*}{ \%var. ${ }^{\mathrm{c}}$} & \multirow[b]{2}{*}{${ }^{c}$ Sig. ${ }^{d}$} \\
\hline & & $\mathrm{O}$ & $\mathrm{N}$ & $\mathrm{D}$ & $\mathrm{J}$ & $\mathrm{F}$ & $\mathrm{M}$ & $\mathrm{A}$ & $\mathrm{M}$ & $\mathrm{J}$ & $\mathrm{J}$ & $\mathrm{A}$ & $\mathrm{S}$ & $\mathrm{O}$ & $\mathrm{N}$ & $\mathrm{O}$ & $\mathrm{N}$ & $\mathrm{D}$ & $\mathrm{J}$ & $F$ & $\mathrm{M}$ & $\mathrm{A}$ & $\mathrm{M}$ & $\mathrm{J}$ & $\mathrm{J}$ & $\mathrm{A}$ & $\mathrm{S}$ & $\mathrm{O}$ & $\mathrm{N}$ & & & & \\
\hline \multirow{2}{*}{ Tree-ring } & Coastal & + & - & + & - & + & + & + & - & - & + & - & - & + & - & - & + & + & + & + & + & + & + & - & + & + & + & + & - & $0.826 \pm 0.040$ & $0.488 \pm 0.132$ & 59 & $* * *$ \\
\hline & Inland & + & - & + & + & - & + & - & - & - & - & - & + & - & - & + & + & + & + & + & + & + & + & + & + & - & + & + & + & $0.912 \pm 0.021$ & $0.661 \pm 0.106$ & 76 & $* * *$ \\
\hline \multirow{2}{*}{ Earlywood } & Coastal & + & + & + & - & + & + & + & - & - & + & + & + & + & - & + & + & + & + & + & + & + & + & - & + & - & + & + & - & $0.819 \pm 0.043$ & $0.437 \pm 0.140$ & 58 & $* * *$ \\
\hline & Inland & + & - & + & + & - & + & - & - & - & - & - & + & - & - & + & + & + & + & + & + & + & + & + & + & - & - & + & + & $0.878 \pm 0.030$ & $0.537 \pm 0.137$ & 68 & $* * *$ \\
\hline \multirow{2}{*}{ Latewood } & Coastal & + & - & + & + & + & + & + & - & - & - & - & - & + & - & - & + & + & + & + & + & - & + & - & + & + & + & + & + & $0.848 \pm 0.041$ & $0.543 \pm 0.127$ & 63 & $* * *$ \\
\hline & Inland & + & - & + & + & - & + & - & + & - & - & $=$ & + & + & - & - & + & + & + & + & + & + & + & + & + & + & + & + & + & $0.929 \pm 0.019$ & $0.745 \pm 0.080$ & 81 & $* * * *$ \\
\hline \multicolumn{3}{|c|}{$\begin{array}{l}\text { Negative coefficients: } \\
\text { Positive coefficients: }\end{array}$} & $\begin{array}{l}- \\
+\end{array}$ & & $\begin{array}{l}\text { Sig } \\
\text { Sig }\end{array}$ & & ance & 5000 & & $\begin{array}{l}- \\
+\end{array}$ & & & & & + & & & & & & & & & & & & \multicolumn{3}{|c|}{${ }^{\mathrm{c}} \mathrm{P}$} & nificance $o$ & $\begin{array}{l}\text { explained by } \\
\text { f the model. }\end{array}$ & y climat & \\
\hline
\end{tabular}

Table III. Descriptive statistics of the intra-annual density fluctuations (IADFs). An IADF was identified only when both cores from a tree showed the same IADF in a tree ring.

\begin{tabular}{lcc}
\hline & Coastal & Inland \\
\cline { 2 - 3 } Number of trees (cores) & $25(50)$ & $17(34)$ \\
Trees with IADFs & 25 & 17 \\
Number of rings analyzed & 1381 & 937 \\
Rings with IADFs (\%) & 16.65 & 31.91 \\
Rings with IADFs type $E(\%)$ & 0.07 & 0.11 \\
Rings with IADFs Type $E+(\%)$ & 2.24 & 5.66 \\
Rings with IADFs type $L(\%)$ & 4.42 & 10.25 \\
Rings with IADFs type $L+(\%)$ & 10.5 & 17.29 \\
\hline
\end{tabular}

coastal area and the lower water holding capacity of the soils in the inland area. Fritts et al. [25] showed that mean sensi- tivity, a measure of the relative difference in width between two successive rings, increases with increasing drought stress. In this study, trees in the inland area, growing under drier conditions, showed higher mean sensitivity. The higher latewood/earlywood ratio in the inland trees reflects a higher water stress [18]. According to Domec and Gartner [21], a higher latewood/earlywood ratio could be a strategy for coniferous growth in wet conditions in spring and dry conditions in summer.

For earlywood and tree-ring width, the high first-order autocorrelation indicated a strong dependence of current growth on the previous year's growth. The autocorrelation and mean sensitivity values indicate that latewood was more sensitive to climate than earlywood.

Fritts [23] suggested that trees growing in extreme conditions respond strongly to climatic variations. Accordingly, the climatic response of radial increment of $P$. pinea was higher 

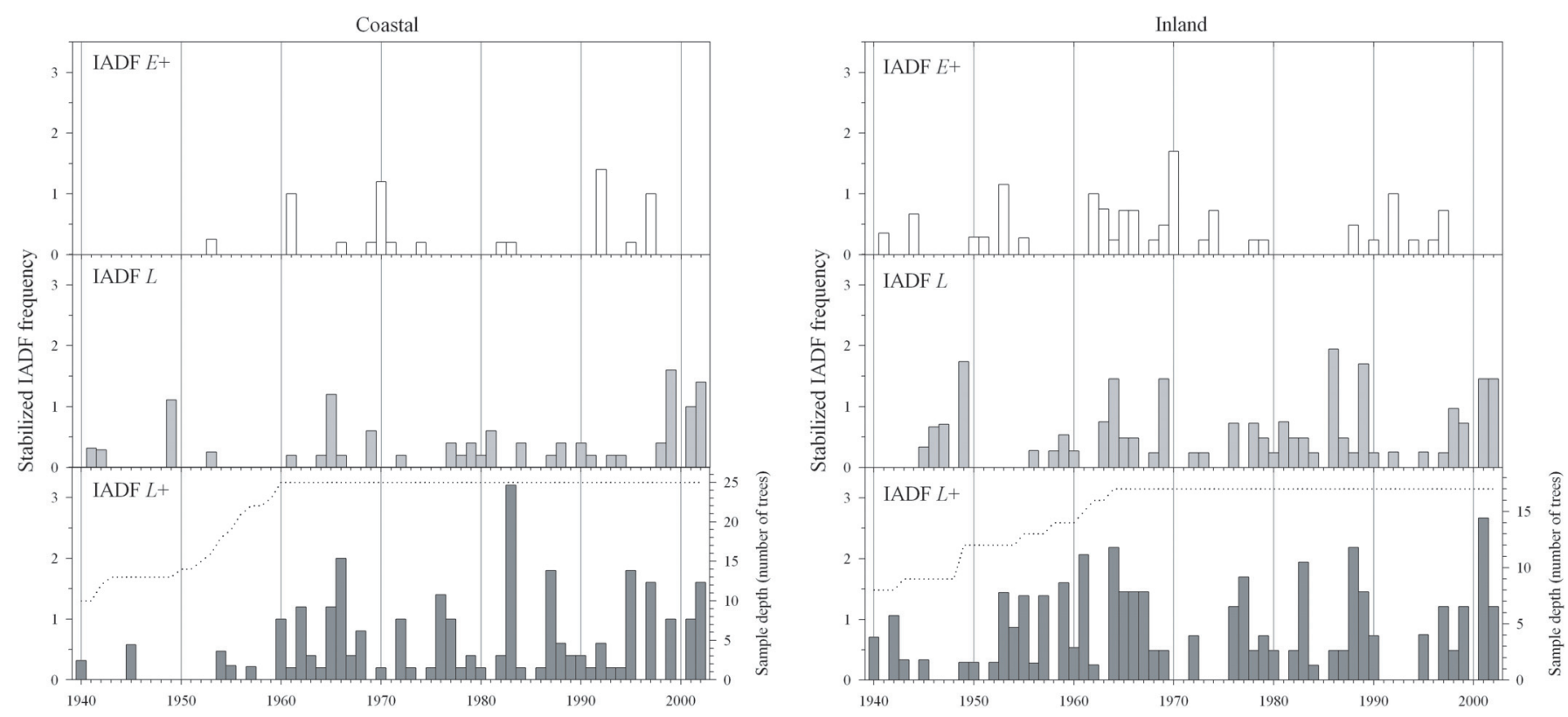

Figure 5. Stabilized IADFs frequency in relation to calendar years. The dot line represents the number of trees ( 2 cores per tree) used for the IADFs study.

in the inland area (Tab. II), where the summer drought is more severe, the winter temperatures are lower and the soils have low water-holding capacity compared to the coastal area.

The climatic conditions during previous winter were as important to earlywood and tree-ring formation as the climate during late spring of current year. In turn, latewood was more strongly associated with climate during the summer concurrent with growth. Tree-ring and earlywood width showed a positive correlation with precipitation from $\operatorname{November}_{(t-1)}$ to February $_{(t)}$, which reflects the importance of winter precipitation on water availability at the beginning of the next growing season, due to recharging of soils. Additionally, for evergreen conifers growing in regions with mild winters, photosynthesis can take place during winter, producing carbohydrates [33], which will be used for earlywood formation in the following year [23].

Liphschitz et al. [37,38] showed that the cambial activity in P. pinea growing in semiarid sites in Israel starts in the middle of February or March and continues until November, without growth intermission in summer. The positive effect of February $(t)$ temperature in earlywood and tree-ring width in the coastal area represented an early interruption of winter dormancy, which means an extension of the growing season and therefore wider tree rings. In this work, a positive relationship between $\mathrm{May}_{(t)}$ precipitation and earlywood and tree-ring width was observed, indicating that cambial activity is driven by water availability during this month. Precipitation in May $_{(t)}$ could result in a good water supply that prolongs earlywood formation and delays latewood production [5, 19,32].

Low precipitation and high temperatures during summer and early autumn are the limiting factor for latewood formation. The negative relationship between August temperature and latewood growth may be due to water stress, since high temperatures increase evapotranspiration and soil water evaporation [49]. We did not observe a significant positive relationship between precipitation in August and latewood formation. August is usually the driest month of the year and rainfall during this month is probably never enough to alleviate water stress and promote formation of new cells. As a result, latewood formation was not sensitive to the range of precipitation in August.

Latewood formation is dependent on carbohydrates produced by photosynthesis, which is very sensitive to water stress and temperature [33]. As a result, summer drought can reduce the net photosynthesis that decreases the supply of carbohydrates for latewood formation and secondary thickening of cell walls. This can explain the negative correlations between temperature in August $(t)$ and latewood formation. Precipitation in September $(t)$ and $\operatorname{October}_{(t)}$ showed a positive correlation with latewood formation. This correlation can be explained by favourable conditions for latewood production.

A water deficit early in the growing season followed by rainfall results in the formation of IADF type $E[50,51,57,62]$. Reduced rates of cell division and cell enlargement occur when the cambium is subjected to internal water stress, producing tracheids with smaller radial diameter [1]. However, cell turgidity recovers rapidly after the water deficit event, and earlywood tracheids are produced [2]. In P. pinea the IADF type $E$ was rare, showing that earlywood development is mostly pre-determined at the beginning of the growing season. This finding confirms the studies of Villalba and Veblen [57], Masiokas and Villalba [40] and Bouriaud et al. [5]. Moreover, $P$. pinea shows a high capacity to store water [42], which could minimize episodic water stress events during the early growing season $[4,39]$. 

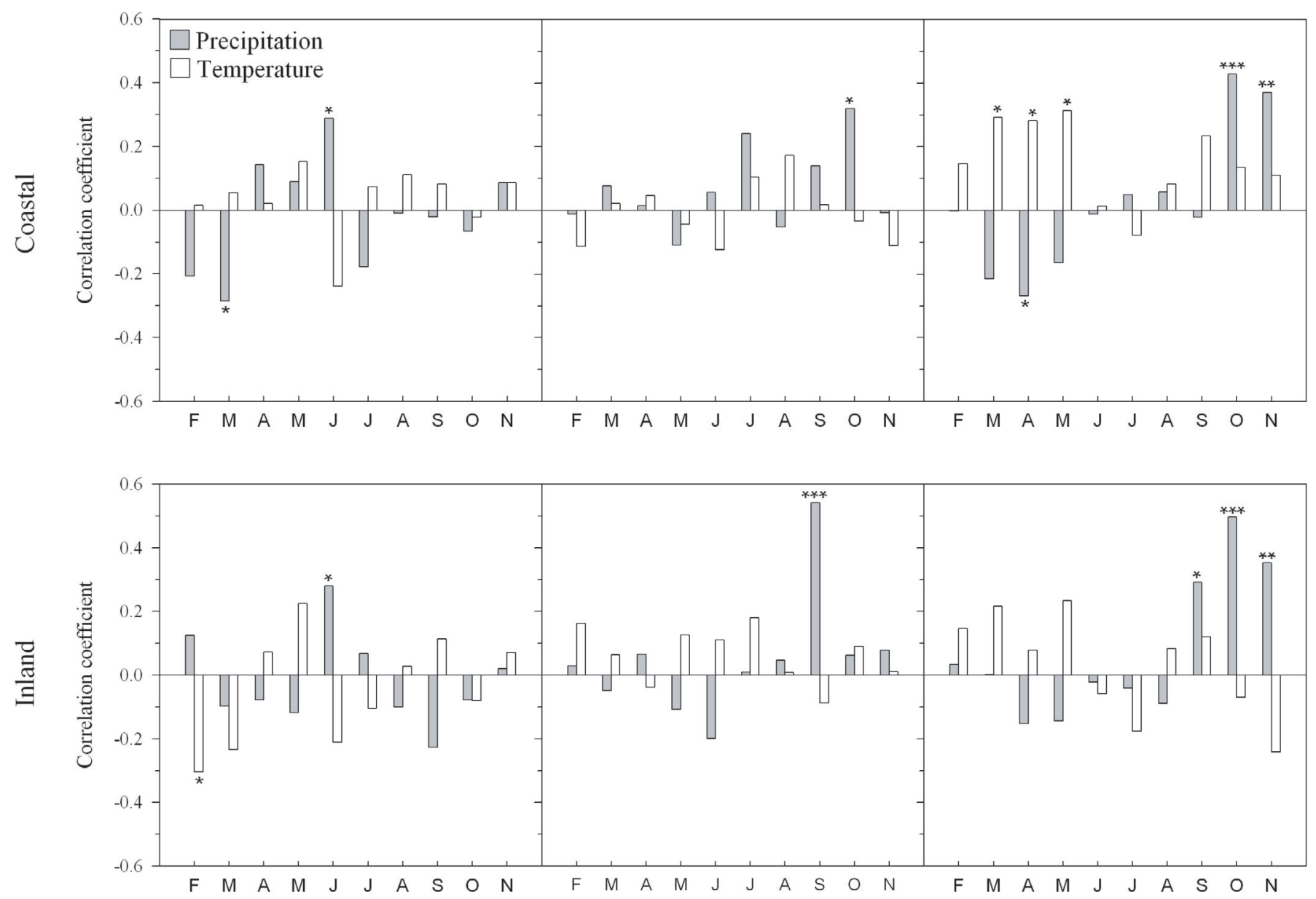

Figure 6. Spearman rank order correlation between the master chronology of standardized frequency of intra-annual density fluctuations in the coastal and inland and monthly climatic data. One, two or three asterisks indicate that correlations are significant at the $95 \%$, 99\% and $99.9 \%$ levels, respectively.

In coniferous species, the earlywood to latewood transition varies from abrupt to gradual. The IADF type $E+$, corresponding to a more gradual transition, was correlated with precipitation in late spring (Fig. 6). In June cell division rate of cambium is normally reduced in response to water deficit [41]. Additionally, the temperature conditions during this period are also favourable for the synthesis and accumulation of cell wall components, leading to the formation of tracheids with thick walls [3]. Those cells are less vulnerable to embolism by water stress, and so increase the safety of water conductance $[21,42]$. When it rains more than average in June the cambium remains producing new cells and the transition from earlywood to latewood is delayed $[47,65]$. Maturing tracheids are larger than normal latewood and secondary wall deposition is not so prominent, leading to a more gradual transition from earlywood to latewood.

The IADF type $L$ is characterized by earlywoodlike cells within the latewood. This type of IADF indicates favourable conditions for tree growth after the dry period in midsummer [31]. In this study, precipitation in $\operatorname{September}_{(t)}$ and $\operatorname{October}_{(t)}$ triggered the IADF type $L$ in the inland and in the coastal area, respectively (Fig. 6). Small increases in tracheid lumen can dramatically increase hydraulic conductivity because flow rate is proportional to the fourth power of the tracheid radius $[55,56]$.

If favourable moisture conditions persist in $\operatorname{November}_{(t)}$ the IADF type $L+$ is produced. According to Masiokas and Villalba [40] the formation of larger cells later in the growing season is a response to greater moisture availability. Antonova and Stasova [3] have suggested that when a certain moisture level is exceeded, a decrease in the deposition of substances in tracheid walls occurs, reducing cell wall thickness. Despite the lack of growth during this period, the IADF type $L+$ for $P$. pinea might be the result of an increase in cell diameter and/or a reduction in the cell wall thickening process. This hypothesis is in agreement with an experimental study in Criptomeria japonica showing that tracheids of trees irrigated every day were larger than trees irrigated every three days [1].

Most of IADFs in $P$. pinea were observed in latewood, as previously observed for other species $[40,46,47]$. These results 
agree with those presented by Bouriaud et al. [5] who found that climatic variations during the first part of the growing season affected growth rate but not wood density. The current results also suggest that the IADF in latewood depend greatly on the specific climatic conditions of the current year, since latewood cells stay more time in the differentiating phase.

\section{CONCLUSIONS}

In southern Portugal, the growth of $P$. pinea was positively correlated with precipitation. IADFs were frequent in $P$. pinea and were mainly observed in latewood. The presence of IADFs was tightly associated with fluctuations in climate parameters during the growing season and its location within the ring is determined by the time when the triggering factor occurs. The IADF type $E+$ was caused by precipitation events early in summer following a water deficit early in the growing season. Pinus pinea responded to early autumn soil water recharge with resumption of rapid radial growth that results in formation of IADF type $L$. The IADF type $L+$ probably occurs when a certain moisture level in the soil was exceeded, leading to an increase in tracheids diameter and consequently decreased wall thickness. Finally, we hypothesize that, in dry areas, IADF formation may be associated with drought tolerance in trees because the adjustment of tracheids traits work as a strategy to keep the balance between hydraulic efficiency and safety throughout intra-season climate variations.

Acknowledgements: Thanks are due to P. Cherubini and P. Fulé for critical comments on an earlier version of this manuscript. The first author would like to thank the colleagues that helped in the field work and S.C. Gonçalves for further discussion. Two anonymous reviewers and the associate editor made valuable suggestions. This research was funded by FCT through a PhD fellowship (SFRH/BD/10677/2002) to F. Campelo.

\section{REFERENCES}

[1] Abe H., Nakai T., Effect of the water status within a tree on tracheid morphogenesis in Cryptomeria japonica D. Don, Trees 14 (1999) $124-129$.

[2] Abe H., Nakai T., Utsumi Y., Kagawa A., Temporal water deficit and wood formation in Cryptomeria japonica, Trees 23 (2003) 859863.

[3] Antonova G.F., Stasova V.V., Effects of environmental factors on wood formation in larch (Larix sibirica Ldb.) stems, Trees 11 (1997) 462-468.

[4] Borghetti M., Cinnirella S., Magnani F., Saracino A., Impact of long-term drought on xylem embolism and growth in Pinus halepensis Mill., Trees 12 (1998) 187-195.

[5] Bouriaud O., Leban J.M., Bert D., Deleuze C., Intra-annual variations in climate influence growth and wood density of Norway spruce, Tree Physiol. 25 (2005) 651-660.

[6] Box G.E.P., Jenkins G.M., Time series analysis: forecasting and control, Holden-Day, San Francisco, 1976.
[7] Briffa K.R., Cook E.R., Methods of response function analysis, in: Cook E.R., Kairiukstis L.A. (Eds.), Methods of dendrochronology: applications in the environmental sciences, Kluwer Academic Publishers, Boston, 1990, pp. 240-247.

[8] Briffa K.R., Jones P.D., Basic chronology statistics and assessment, in: Cook E.R., Kairiukstis L.A. (Eds.), Methods of dendrochronology: applications in the environmental sciences, Kluwer Academic Publishers, Boston, 1990, pp. 137-152.

[9] Brunstein F.C., Climatic significance of the bristlecone pine latewood frost-ring record at Almagre Mountain, Colorado, USA, Arct. Alp. Res. 28 (1996) 65-76.

[10] Camarero J.J., Guerrero-Campo J., Gutiérrez E., Tree-ring growth and structure of Pinus uncinata and Pinus sylvestris in the Central Spanish Pyrenees, Arct. Alp. Res. 30 (1998) 1-10.

[11] Cherubini P., Piussi P., Schweingruber F.H., Spatiotemporal growth dynamics and disturbances in a subalpine spruce forest in the Alps: A dendroecological reconstruction, Can. J. For. Res. 26 (1996) 9911001.

[12] Cherubini P., Gartner B.L., Tognetti R., Bräker O.U., Schoch W., Innes J.L., Identification, measurement and interpretation of tree rings in woody species from Mediterranean climates, Biol. Rev. 78 (2003) 119-148.

[13] Cook E.R., A time series analysis approach to tree ring standardization, Ph.D. dissertation, University of Arizona, Tucson, 1985.

[14] Cook E.R., The decomposition of tree-ring series for environmental studies, Tree-Ring Bull. 47 (1987) 37-59.

[15] Cook E.R., Peters K., The smoothing spline: A new approach to standardizing forest interior tree-ring width series for dendroclimatic studies, Tree-Ring Bull. 41 (1981) 45-55.

[16] Cook E.R., Shiyatov S., Mazepa V., Estimation of the mean chronology, in: Cook E.R., Kairiukstis L.A. (Eds.), Methods of dendrochronology: applications in the environmental sciences, Kluwer Academic Publishers, Boston, 1990, pp. 123-132.

[17] Cook E.R., Briffa K.R., Shiyatov S., Mazepa V., Tree-ring standardization and growth-trend estimation, in: Cook E.R., Kairiukstis L.A. (Eds.), Methods of dendrochronology: applications in the environmental sciences, Kluwer Academic Publishers, Boston, 1990, pp. 104-123.

[18] Creber G.T., Chaloner W.G., Influence of environmental factors on the wood structure of living and fossil trees, Bot. Rev. 50 (1984) $357-448$.

[19] Cregg B.M., Dougherty P.M., Hennessey T.C., Growth and wood quality of young loblolly-pine trees in relation to stand density and climatic factors, Can. J. For. Res. 18 (1988) 851-858.

[20] Delwaide A., Filion L., Payette S., Spatiotemporal distribution of light rings in subarctic black spruce, Quebec, Can. J. For. Res. 21 (1991) 1828-1832.

[21] Domec J.-C., Gartner B.L., How do water transport and water storage differ in coniferous earlywood and latewood? J. Exp. Bot. 53 (2002) 2369-2379.

[22] Douglass A.E., Climatic cycles and tree-growth. Vol. II. A study of the annual rings of trees in relation to climate and solar activity, Carnegie Inst. Wash. Publ. 289 (1928) 1-166.

[23] Fritts H.C., Tree rings and climate, Academic Press, London, 1976.

[24] Fritts H.C., PRECON version 5.17b, http://www.ltrr.arizona.edu/ webhome/hal/dlprecon.html, 1999.

[25] Fritts H.C., Smith D.G., Cardis J.W., Budelsky C.A., Tree-ring characteristics along a vegetation gradient in Northern Arizona, Ecology 46 (1965) 393-401. 
[26] Glock W.S., Tree growth II. Growth rings and climate, Bot. Rev. 21 (1955) 73-188.

[27] Guiot J., Methods of calibration, in: Cook E.R., Kairiukstis L.A. (Eds.), Methods of Dendrochronology: Applications in the Environmental Sciences, Kluwer Academic Publishers, Boston, 1990, pp. $165-178$.

[28] Guiot J., The bootstrapped response function, Tree-Ring Bull. 51 (1991) 39-41.

[29] Holmes R.L., Computer-assisted quality control in tree-ring dating and measurement, Tree-Ring Bull. 43 (1983) 69-75.

[30] Holmes R.L., Dendrochronology program library, Tucson, Laboratory of Tree-ring Research, University of Arizona, 1994.

[31] Jayawickrama K.J.S., McKeand S.E., Jett J.B., Wheeler E.A., Date of earlywood-latewood transition in provenances and families of loblolly pine, and its relationship to growth phenology and juvenile wood specific gravity, Can. J. For. Res. 27 (1997) 1245-1253.

[32] Kozlowski T.T., Growth and development of trees. Vol. II, Academic Press, New York, 1971.

[33] Kozlowski T.T., Kramer P.J., Pallardy S.G., The physiological ecology of woody plants, Academic Press, New York, 1991.

[34] Kuo M.-L., McGinnes E.A., Variation of anatomical structure of false rings in Eastern red cedar, Wood Sci. 5 (1973) 205-210.

[35] LaMarche V.C., Hirschboeck K.K., Frost rings in trees as records of major volcanic-eruptions, Nature 307 (1984) 121-126.

[36] Liang C., Filion L., Cournoyer L., Wood structure of biotically and climatically induced light rings in eastern larch (Larix laricina), Can. J. For. Res. 27 (1997) 1538-1547.

[37] Liphschitz N., Lev-Yadun S., Cambial activity of evergreen and seasonal dimorphics around the Mediterranean, IAWA Bull. 7 (1986) $145-153$.

[38] Liphschitz N., Lev-Yadun S., Rosen E., Waisel Y., The annual rhythm of activity of the lateral meristems (cambium and phellogen) in Pinus halepensis Mill. and Pinus pinea L., IAWA Bull. 5 (1984) 263-274.

[39] Loustau D., Berbigier P., Roumagnac P., Arruda-Pacheco C., David J.S., Ferreira M.I., Pereira J.S., Tavares R., Transpiration of a $64-$ year-old maritime pine stand in Portugal.1. Seasonal course of water flux through maritime pine, Oecologia 107 (1996) 33-42.

[40] Masiokas M., Villalba R., Climatic significance of intra-annual bands in the wood of Nothofagus pumilio in southern Patagonia, Trees 18 (2004) 696-704.

[41] Nicault A., Rathgeber C., Tessier L., Thomas A., Observations sur la mise en place du cerne chez le pin d'Alep (Pinus halepensis Mill.): confrontation entre les mesures de croissance radiale, de densité et les facteurs climatiques, Ann. For. Sci. 58 (2001) 769 784.

[42] Oliveras I., Martínez-Vilalta J., Jimenez-Ortiz T., Lledó M.J., Escarré A., Piñol J., Hydraulic properties of Pinus halepensis, Pinus pinea and Tetraclinis articulata in a dune ecosystem of Eastern Spain, Plant Ecol. 169 (2003) 131-141.

[43] Osborn T.J., Briffa K.R., Jones P.D., Adjusting variance for samplesize in tree-ring chronologies and other regional mean time series, Dendrochronologia 15 (1997) 89-99.

[44] Priya P.B., Bhat K.M., Wood anatomical changes in juvenile teak due to insect defoliation, IAWA 18 (1997) 311-317.

[45] Priya P.B., Bhat K.M., False ring formation in teak (Tectona grandis L.f.) and the influence of environmental factors, For. Ecol. Manage. 108 (1998) 215-222.
[46] Rigling A., Bräker O., Schneiter G., Schweingruber F., Intraannual tree-ring parameters indicating differences in drought stress of Pinus sylvestris forests within the Erico-Pinion in the Valais (Switzerland), Plant Ecol. 163 (2002) 105-121.

[47] Rigling A., Waldner P.O., Forster T., Bräker O.U., Pouttu A., Ecological interpretation of tree-ring width and intraannual density fluctuations in Pinus sylvestris on dry sites in the central Alps and Siberia, Can. J. For. Res. 31 (2001) 18-31.

[48] Rinn F., TSAP-Win - Time series analysis and presentation dendrochronology and related applications, Frank Rinn, Heidelberg, 2003.

[49] Rozas V., Dendrochronology of pedunculate oak (Quercus robur L.) in an old-growth pollarded woodland in northern Spain: tree-ring growth responses to climate, Ann. For. Sci. 62 (2005) 209-218.

[50] Rozenberg P., Van Loo J., Hannrup B., Grabner M., Clonal variation of wood density record of cambium reaction to water deficit in Picea abies (L.) Karst, 59 (2002) 533-540.

[51] Schulman E., Classification of false annual rings in Monterey pine, Tree-ring Bull. 4 (1938) 4-7.

[52] Schweingruber F.H., Tree rings and environment - Dendroecology, Haupt, Bern, 1996.

[53] Serre-Bachet F., Tessier L., Response function analysis for ecological study, in: Cook E.R., Kairiukstis L.A. (Eds.), Methods of dendrochronology: applications in the environmental sciences, Kluwer Academic Publishers, Boston, 1990, pp. 247-258.

[54] Stokes M.A., Smiley T.L., An introduction to tree-ring dating, University of Chicago Press, Chicago, 1968.

[55] Tyree M.T., Ewers F.W., The hydraulic architecture of trees and other woody-plants, New Phytol. 119 (1991) 345-360.

[56] Tyree M.T., Zimmermann M.H., Xylem structure and the ascent of sap, Springer Verlag, Berlin, Germany, 2002.

[57] Villalba R., Veblen T.T., A tree-ring record of dry spring wet summer events in the forest-steppe ecotone, northern Patagonia, Argentina, in: Dean J.S., Meko D.M., Swetnam T.W. (Eds.), Tree Rings, Environment and Humanity, Radiocarbon, Spec. Issue, 1996, pp. $107-116$.

[58] Wang L., Payette S., Begin Y., Relationships between anatomical and densitometric characteristics of black spruce and summer temperature at tree line in northern Quebec, Can. J. For. Res. 32 (2002) $477-486$.

[59] Wigley T.M.L., Briffa K.R., Jones P.D., On the average value of correlated time series, with applications in dendroclimatology and hydrometeorology, J. Clim. Appl. Met. 23 (1984) 201-213.

[60] Wimmer R., Wood anatomical features in tree-rings as indicators of environmental change, Dendrochronologia 20 (2002) 21-36.

[61] Wimmer R., Grabner M., Effects of climate on vertical resin duct density and radial growth of Norway spruce Picea abies (L.) Karst, Trees 11 (1997) 271-276.

[62] Wimmer R., Strumia G., Holawe F., Use of false rings in Austrian pine to reconstruct early growing season precipitation, Can. J. For. Res. 30 (2000) 1691-1697.

[63] Yamaguchi D.K., A simple method for cross-dating increment cores from living trees, Can. J. For. Res. 21 (1991) 414-416.

[64] Yamaguchi D.K., Filion L., Savage M., Relationship of temperature and light ring formation at subarctic treeline and implications for climate reconstruction, Quat. Res. 39 (1993) 256-262.

[65] Zahner R., Water deficits and growth of trees, in: Kozlowski T.T. (Ed.), Water deficits and plant growth, Vol. II, Academic Press, London, 1968, pp. 191-254. 